\title{
The Influence of Animal Welfare in the Quality of Bovine Meat
}

\author{
Ferro Palma $\mathrm{S}^{1 *}$, Mamede $\mathrm{N}^{1}$, Fernandes $\mathrm{I}^{2}$ and Barata de Carvalho $\mathrm{MJ}^{1}$ \\ ${ }^{1}$ DTCA, Escola Superior Agrária, Instituto Politécnico de Beja, Portugal \\ ${ }^{2}$ Matadouro da Sapju Carnes, Portugal
}

Submission: May 07, 2019; Published: June 04, 2019

*Corresponding author: Ferro Palma S, DTCA, Escola Superior Agrária, Instituto Politécnico de Beja, Portugal

\section{Abstract}

Animal welfare science can have a significant economic impact in certain industries [1] thus in order to monitor, audit, and optimize the welfare of animals at the time of slaughter, a valid, feasible and reliable welfare assessment protocol should be used [2]. This study aim in a first approach was to verify internal procedures developed in SAPJU abattoir in order to respect legislation concerning animal welfare preslaughtering. Afterwards to verify how that welfare respected procedures were recognized in meat quality by means of pH measures, which enlightens the influence of ante-mortem stress in meat quality. In this study was measured animals' welfare during the arrival and its unloaded in the abattoir until bleeding step. After slaughtering both $\mathrm{pH}$ and animal's temperature at $45 \mathrm{~min}$ and $24 \mathrm{~h}$ was measured. That monitorization was through by means of a control list with several parameters to register previously to slaughterer which allows to evaluate the animal welfare as soon as it arrives to the enterprise and along its staying until bleeding stage. Animal welfare control is important not just to respect legislations standards but also as an important factor to assure meat final quality.

With this study was possible to conclude that animal handling previous to its slaughter in SAPJU was done by the standard rule Reg [3] and therefore the majority carcasses had shown $\mathrm{pH}$ from 5,5 to 5,9 along the $24 \mathrm{~h}$ after slaughter, which were normal pH values. Thus, handlers should be aware of the behavioral signs of fear and distress in the different species of animals and thus directly promote the animal's welfare and hence the meat quality.

Keywords: Slaughterhouse; Rigor mortis; Stunning; pH; Ante-mortem stress

\section{Introduction}

Meat quality is influenced by several factors, namely, animal breed, gender, feeding and above all handling, therefore animal welfare has hinge influence in final meat quality. Animals in stress will generate meat with worst quality with unacceptable $\mathrm{pH}$ values. Animal welfare in slaughterhouse is an actual subject [3] from 24th September European Council) which control is of extreme importance and hence it's an essential factor in final meat characteristics. Besides it translates muscle conversion in meat, which is control by $\mathrm{pH}$, and thus allows evaluating the ante-mortem stress influence in meat quality. The pre-slaughter handling, the aggressive abuse will provoke not only stress in the animals, and consequently compromising animal's welfare, but also induces a negative influence in meat quality, besides that meat can be rejected due to bruises [4]. The stress pre-slaughter can have negative consequences to meat quality, increasing the risk of PSE meats (pale, soft and exudative) and DFD meats (dark, firm and dry) [5].
Further, exhausted animals make meat with lower storage time due to an incomplete development of muscle acidity and consequent earlier microflora invasion [6]. Welfare absence can conduce to meats with lower quality, which results in production drop, selling lacking or product sell with minor quality [7]. In general terms, the carcass and meat quality depend in extrinsic and intrinsic factors. The most important intrinsic factors are genetic, nutrition, age and gender. Among the extrinsic factors, the slaughter conditions since the animal's arrival until the slaughter stage are very important. The cold-shortening might be due to the lipid- protein system in sarcoplasmic reticule membrane to low temperatures and calcium pump. The cold-shortening and toughness risks in meat can be reduce by electrical stimulation.

\section{Material and Methods}

For this study developed in Beja abattoir Sapju Carnes, S.A were made daily monitorization along 4 weeks by observation 
and registration of the bovine's slaughter practice, and the welfare animals' conditions previous to the slaughter in order to control the respect of the standard legislation procedures [3]. The welfare conditions were verified during the animal's unload and until it is bleeding. The monitorization was through by means of a control list with a number of parameters to register previously to slaughterer which allows evaluating the animal welfare as soon as it arrives to the abattoir, since animal's unloaded stage, stunning and bleeding. The control list is based on the HACCP protocols commonly used to monitor food hygiene and safety, where a small number of measures can be used to identify a large number of potential risks, in addition the five animal based measures used are [8]: 1 - percentage of animals stunned effectively on the first attempt; 2 - percentage of animals that remains insensible after they are hung on the rail; 3 - percentage of animals that fall during handling; 4 - percentage of animals that vocalize during handling and stunning; 5 - percentage of animals moved with an electric goad.

Animal breed was registered, animal classification, weight, age and after slaughter $\mathrm{pH}$ was measured at $45 \mathrm{~min}$ and 24h. $\mathrm{pH}$ measurement was made with a portable equipment (potentiometric method) in the Longissimus Dorsis muscle in the $10^{\text {th }}$ rib and in the Gluteus medius, in the animal back, both in the left and right part of the carcass, and also the animal temperature was measured. The animals transport vehicles had presented the demanding conditions required by SAPJU CARNES S.A., and the animals were cleaning and without pain and bruises. The slaughtered breeds for this study were: Alentejana and Wolstein Frisia, but it was also slaughtered animals of undefined breed, animals of cross breeds and cross breed with Limousine and cross breed with Frisia. The results were analyzed breed by breed and presented in $\mathrm{pH}$ means, in order to evaluate the influence of animal welfare in the meat $\mathrm{pH}$ and thus classify the meat in normal, PSE or DFD.

\section{Discussion}

During the handling of animals to the slaughterhouse, the electrical goad was applied with moderation, according Reg. (CE) no 1099/2009, shall only be used for adult bovine animals which refuse to move, and only when they have room ahead of them in which to move. The shocks shall last no longer than one second, be adequately spaced and shall only be applied to the muscles of the hindquarters. Shocks shall not be used repeatedly if the animal fails to respond, for exception of Alentejana breed and cross milk which presented more resistance. Animals vocalize sometimes along the way to the slaughterhouse probably due to the fear felt or due to something unidentified that bothers the animal (Figure 1). Stunning was correctly applied in the first attempt, for exception of one case where the animal had moved and thus the handler fail the shot. The time between stunning and bleeding had been superior to the recommendable time (60s) in some animals, mainly in those which characteristics difficult the handler manipulation, such has the animal volume and the involuntary muscle contractions.

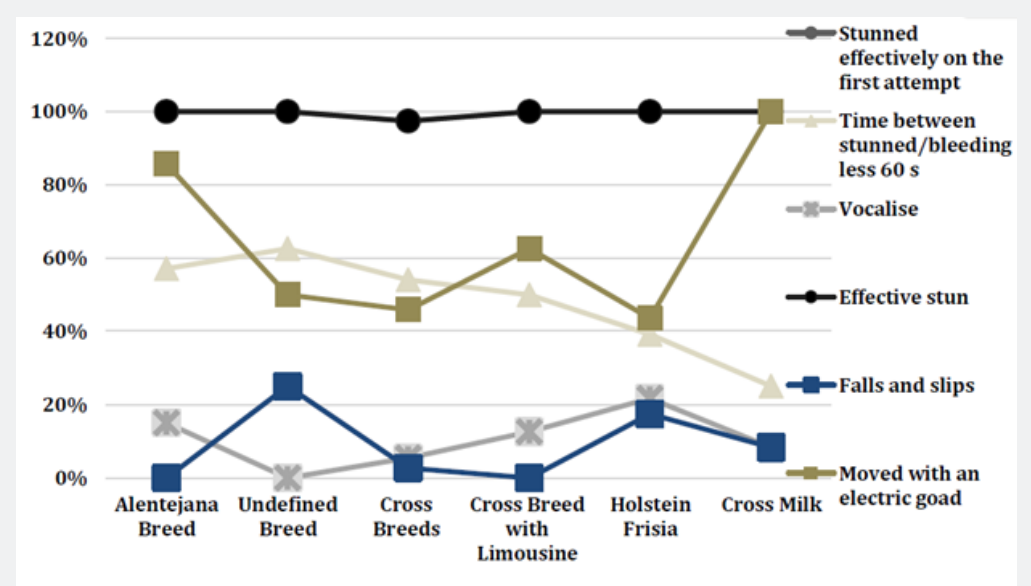

Figure 1: Monitorization of pre-slaughter handling conditions in the different breeds.

Overall, the pre-slaughter handling had been performed in accordance to what was stablish in legislation and, therefore, the majority of carcasses had $\mathrm{pH}$ between 5,5 and 5,9 at $24 \mathrm{~h}$ after slaughter, which are considerable normal values in bovine meat. The $\mathrm{pH}$ values had not presented significant differences which might be related with the breed in study. The temperature decrease had been directly influencing by the carcass weight and moreover by the fattening state. Indeed, animals that become stressed shortly before slaughter will have higher lactate levels and be more likely to have tougher meat. A calm animal that has not become agitated and fearful will also move more easily and be safer for people to handle [9]. Thus, the rate of muscle $\mathrm{pH}$ decline has the potential to indicate the level of stress experienced by an animal during the slaughter process, however, as with some other forms of biological measures, does not allow for the "pinpointing" of potential stressors [2].

\section{Conclusion}

With this study, it was possible to conclude pre-slaughter handling had been performed in Sapju Carnes, S. A in accordance 
to what was stablish in legislation Reg [9]. It was concluded that during the handling of animals to the slaughterhouse, the electrical goad was applied with moderation, for exception of Alentejana breed and cross milk which presented more resistance. The time between stunning and bleeding had been superior to the recommendable time $(60 \mathrm{~s})$ in some animals. In the majority of carcasses, $\mathrm{pH}$ had been between 5,5 and 5,9 at 24h after slaughter, which are considerable normal values in bovine meat. The $\mathrm{pH}$ values had not presented significant differences which might be related with the breed in study. The temperature decrease had been directly influencing by the carcass weight, and moreover by the fattening state. Therefore, biological measurements may be useful as part of an overall welfare assessment and method to evaluate meat quality, and the abattoirs should keep ongoing for the need to involved all the personnel in this issue, mainly the handlers should be aware of the behavioral signs of fear and distress in the different species of animals and thus directly promote the animals welfare and hence the meat quality.

\section{References}

1. Gallo CB, Huertas SM (2016) Main animal welfare problems in ruminant livestock during preslaughter operations: A South American view. Animal 10(2): 357-364.
2. Wigham EE (2018) Assessing cattle welfare at slaughter - Why is it important and what challenges are faced? Meat Science 145: 171-177.

3. Regulamento (CE) no (2009) do Parlamento Europeu e do Conselho de 22 de Setembro de 2009. Proteção dos animais no momento da occisão, Jornal Oficial da União Europeia, L303. Bruxelas.

4. Barbalho PC (2007) Avaliação de programas de treinamento em manejo racional de bovinos em frigoríficos para melhoria do bemestar animal. Dissertação de Mestrado, Faculdade de Ciências Agrárias e Veterinária, Universidade Estadual Paulista, Jaboticabal, SP

5. Gregory NG (1998) Animal Welfare and Meat Science, CABI Publishing, Reino Unido, UK.

6. Faucitano Luigi (2000) Efeitos do Manuseio Pré-Abate sobre O BemEstar Animal e a sua Influência sobre a Qualidade da carne, EMBRAPA 1a Conferência Internacional Virtual sobre Qualidade de Carne Suína, Bem-estar, Transporte, Abate e Consumidor, Ministério da Agricultura e Abastecimento 16 de Novembro a 16 de Dezembro de 2000,Concórdia, SC

7. Warris PD (1994) Ante mortem factors influencing the yield and quality of meat from farm animals - In quality and grading of carcasses of meat animals. Jones SDM (Eds.), CRC Press, Boca Raton, USA, 15: 199.

8. Grandin T (2010) Auditing animal welfare at slaughter plants. Meat Science 86(1): 56-65.

9. Grandin T (2019) Slaughter Plants: Behavior and Welfare Assessment. Encyclopedia of Animal Behavior (Second Edition) pp. 153-162.

\section{Your next submission with Juniper Publishers will reach you the below assets}

- Quality Editorial service

- Swift Peer Review

- Reprints availability

- E-prints Service

- Manuscript Podcast for convenient understanding

- Global attainment for your research

- Manuscript accessibility in different formats

( Pdf, E-pub, Full Text, Audio)

- Unceasing customer service

Track the below URL for one-step submission https://juniperpublishers.com/online-submission.php 